Session 3453

\title{
Integration of Service Learning into a Freshman Engineering Course
}

\author{
William Oakes \& Michael Thompson \\ Purdue University
}

\begin{abstract}
Service learning (SL) is a pedagogy that integrates community service into the academic experience. Studies have shown that service learning can positively impact student learning, provides a rich environment for students to learn the "soft" skills that are often difficult to teach in traditional classes, can increase retention in participants, and can broaden the view of engineering among the participants. Service-learning can greatly enhance the services of local community service organizations that lack the technical staffs and/or resources to take full advantage of current technology. The potential benefits of service learning have motivated the Department of Freshman Engineering at Purdue to begin implementing service learning into the first-year engineering courses. 143 students participated in an service-learning experience at Purdue University in the Fall semester of 2003. Student and community partner evaluations have shown initial success and in depth investigations are underway to characterize these experiences.
\end{abstract}

\section{Introduction}

Over the past ten years, engineering has been undergoing a reform of its educational models. We have seen a significant increase in emphasis on design and on the wide range of skills that engineering students will need when they enter the workplace (ASEE, 1994; ASEE, 1995; Dahir, 1993; Hissey, 2000; Peterson, 1993; Valenti, 1996; Fromm 2003). Among the most dramatic statements about these skills has been the set of program outcomes at the heart of the engineering accreditation guidelines that went into effect in 2000, dubbed "Engineering Criteria 2000" (ABET, 2000; ABET, 2002). Under EC 2000, in addition to "traditional" engineering knowledge of mathematics, science, and engineering and experience in engineering problem solving and system design, students are mandated to be able to function on multidisciplinary teams, to communicate effectively, and to understand a wide range of issues in engineering. These issues include: professional and ethical responsibility, the impact of engineering solutions in a global and societal context, and a knowledge of contemporary issues. While recognizing its importance within the engineering curriculum, many departments find it difficult to effectively integrate experiences that include the full spectrum of professional, or "soft" skills, that simulate current industrial practices (Hughes, 2001).

"Proceedings of the 2004 American Society for Engineering Education Annual Conference \& Exposition Copyright (C) 2004, American Society for Engineering Education" 
Service-learning, which integrates community service with academic learning, has the potential to integrate many of these aspects in the curriculum. The pedagogy is consistent with the literature on recruitment and retention of women in science and engineering with its social context; emphasis on general educational goals including communication; employment of cooperative and interdisciplinary approaches; and problems with a "holistic, global scope" (Noddings, 1992; Rosser, 1990; Rosser, 1995). Matyas and Malcolm (1991) and Oakes, Gamoran, and Page (1992) suggest that many of the same factors are relevant for attracting and retaining minorities. In a UCLA study of retention of engineers in general, it is suggested that one factor contributing to engineering's low retention rates is the failure of engineering faculty to value such educational goals as teaching personal values, enhancing self-understanding, and supporting emotional development (Astin, 1993). Service-learning integrates all of these aspects and has proven to be effective in enhancing learning.

While engineering educators seek to provide learning environments that prepare students for life as professionals, community service and education agencies face a future in which they must rely to a great extent upon technology for the delivery, coordination, accounting, and improvement of the services they provide. They often possess neither the expertise to use nor the budget to design and acquire a technological solution that is suited to their mission. They thus need the help of people with strong technical backgrounds. Service learning links these two needs and provides a means to enhance both the community and undergraduate education.

While service-learning has been well established in many disciplines in higher education, engineering as a whole has been much slower to adopt the pedagogy (Tsang 2000). There are examples of service-learning that have been effectively integrated and used in an engineering contexts [ Duffy, J., Tsang, E., and Lord, S]. Examples include first-year introductory courses [Hobson,Tsang], capstone senior design courses [Catalono], multidisciplinary approaches [Nagchaudhuri, A., Eydgahi, A., and Shakur, Coyle 1997] and integration of co-curricular activities [Stott, N. W., Schultz, W. W., Brei, D., Winton Hoffman, D. M., and Markus, G.].

Purdue University has integrated service learning into a multidisciplinary and vertically integrated course structure that is centered on long-term engineering projects through the Engineering Projects in Community Service (EPICS) Program. Although no formal evaluation has yet focused on the experiences of the female students in EPICS, it appears that EPICS is serving as an effective vehicle for encouraging women in engineering and computer science. Over a five-year window, enrollment of women in ECE and ME at Purdue ranged from $10 \%$ to $12 \%$, while $20 \%$ of ECE and ME students in EPICS were women. In Spring 2001, 33\% of the CS students in EPICS were women, compared to $11.5 \%$ of the undergraduates in CS. In the first three years of the program, during which time $20 \%$ of the students in EPICS were women, approximately $30 \%$ of the team leaders were women.

The success of engineering service-learning programs including Purdue's own EPICS program has motivated the Department of Freshman Engineering to integrate service-learning into its first-year courses. This paper details the integration of service-learning into the first required engineering course for Purdue engineering students.

"Proceedings of the 2004 American Society for Engineering Education Annual Conference \& Exposition Copyright $\mathbb{0}$ 2004, American Society for Engineering Education" 


\section{Purdue University's Freshman Engineering}

Purdue University's Department of Freshman Engineering has responsibility for all of the approximately 1650 first-year engineering students. All engineering students are required to complete a common first year core of classes shown in Table 1 before matriculating to their respective engineering major. Minimum grade levels are established for matriculation to the major of their choice. The department includes seven tenure track faculty and four academic advisors. This department has the responsibility for all of the academic advising for first-year students and primary teaching responsibility for the engineering lectures, seminars, help and assistance courses as well as the first engineering course, ENGR 106 - Engineering Problem Solving and Computer Tools.

Table 1: Purdue University First- Year Engineering Curriculum

\begin{tabular}{|l|}
\hline \multicolumn{1}{|c|}{ Fall Semester } \\
\hline Calculus I \\
\hline Chemistry I \\
\hline Engineering Lectures (+ seminar option) \\
\hline Engineering Problem Solving and Computer Tools \\
\hline English or Communications \\
\hline Optional Electives \\
\hline
\end{tabular}

\begin{tabular}{|l|}
\hline \multicolumn{1}{|c|}{ Spring Semester } \\
\hline Calculus II \\
\hline Chemistry II \\
\hline Physics (Mechanics) \\
\hline Computer Programming (C or Fortran) \\
\hline English or Communications \\
\hline \\
\hline
\end{tabular}

\section{Integration of Service-Learning}

A number of options for implementing service-learning into the first year have been considered. The EPICS program at Purdue has demonstrated significant success but only can accommodate approximately 300 students each semester. With 1600+ first-year students each year, this is not currently a viable option for a large percentage of the first-year students. A second option that was considered folded service-learning into the first-year seminar courses. Students have the option of taking a one credit seminar classes. This concept was piloted with very mixed results. The one credit seminars did not allow enough time or flexibility and resulted in frustration by the students.

The first engineering course, ENGR 106 - Engineering Problem Solving and Computer Tools, offered an attractive alternative. Approximately 1400 students are enrolled each fall with an additional 500 each spring semester. The learning objectives for the course state that a student completing the course will:

- Develop a logical problem solving process which includes sequential structures, conditional structures, and repetition structures for fundamental engineering problems,

- Translate a written problem statement into a mathematical model,

- Solve fundamental engineering problems using computer tools,

"Proceedings of the 2004 American Society for Engineering Education Annual Conference \& Exposition Copyright $\mathbb{0}$ 2004, American Society for Engineering Education" 
- Perform basic file management tasks using an appropriate computer tool,

- Work effectively and ethically as a member of a technical team, and

- Develop a work ethic appropriate for the engineering profession.

The class is taught with a team-based learning environment and problem solving is emphasized throughout the course. Multiple sections of the course are offered with common assignments and exams across all of the divisions. Students attend two lectures and a computer lab each week. Students are assigned formal teams and complete two large projects each semester. The first project is typically a hands-on or design-build style of project that integrates simple (e.g. spreadsheet) computer tools and analysis. The second project is typically a more intense computer application and programming project. The first project aligned well with the goals of service learning. This first projects offered an excellent opportunity for integrating service-learning

\section{First-Year Learning Communities}

In parallel with the introduction of service-learning there has been an initiative at Purdue to implement learning communities for first-year students. Engineering has been a major participant in this initiative. For the fall semester of 2003, approximately 240 engineering students were enrolled in one of three learning communities directed by the Department of Freshman Engineering. Each learning community consisted of a series of linked classes where cohorts of students were registered together and participated in co-curricular activities. Some learning communities also offered a residential component where students were assigned to the same floor of a residence hall. Service-learning was and has been integrated as a curricular tie for all three of the Freshman Engineering Learning Communities.

Students elected to participate in a learning community. Information about the learning communities was distributed in the spring and students registered for them as part of the class and housing registration process. The expectation of a service-learning project was made clear to each participant. The honors learning community was only open to students in the Engineering Honors Program. This paper will focus on the implementation of service-learning in the Network and IDEAS teaching communities that were open to all first-year engineering students. All of the students in these two learning communities were placed in the same division of ENGR 106 - Engineering Problem Solving and Computer Tools which facilitated adapting the course to a service-learning model

Table 2: First-Year Engineering Learning Communities

\begin{tabular}{|l|l|l|l|l|}
\hline $\begin{array}{l}\text { Learning } \\
\text { Community }\end{array}$ & Enrollment & Linked classes & $\begin{array}{l}\text { Residential } \\
\text { Component }\end{array}$ & $\begin{array}{l}\text { Service- } \\
\text { learning }\end{array}$ \\
\hline Honors & 96 & $\begin{array}{l}\text { Honors Seminar } \\
\text { Honors Engr. Problem } \\
\text { Solving }\end{array}$ & Required & Required \\
\hline Network & 123 & $\begin{array}{l}\text { Engr. Problem Solving } \\
\text { English or Communication }\end{array}$ & Optional & Required \\
\hline
\end{tabular}

"Proceedings of the 2004 American Society for Engineering Education Annual Conference \& Exposition Copyright $\mathbb{0}$ 2004, American Society for Engineering Education" 


\begin{tabular}{|l|l|l|l|l|}
\hline & & Seminar & & \\
\hline IDEAS & 19 & $\begin{array}{l}\text { Engr. Problem Solving } \\
\text { English or Communication } \\
\text { Seminar }\end{array}$ & Required & Required \\
\hline
\end{tabular}

\section{Implementing service-learning}

Implementing a high-quality service-learning experience for approximately 140 students presented many challenges. The first step was to solicit projects from the community. Materials were distributed through channels of the university's public relations department, the local volunteer bureau and through personal contacts. Each potential community partner was given a description of the program including the constraints and expectations of the service-learning experience. We wanted to keep the learning community cohorts together so we sought opportunities where groups of 10 to 14 students could participate at the same community organization. This size was designed to match the size of the seminar courses, one of the three linked classes. Students were assigned to teams of 3 or 4 students, so a seminar class of 10 would have three teams and a seminar class of 14 would have 4 teams. The teams could work on the same projects, different or duplicate projects (e.g. if they were modifying a website, they could each work on different designs and we select one of the products to be implemented)

We let the service providers know upfront that these were first-year students who are involved in this program in their very first semester. This was important to clarify expectations. Some had experience with other engineering programs and we had to distinguish ourselves and set proper expectations. The following are examples of what we told the community member the first semester freshmen should be able to do:

- Web page design and implementation .

- Preliminary design, feasibility studies or research (e.g. traffic flow around a facility, computer or networking needs, automation or upgrades). While the students may not have the expertise yet, they are able to do research and find the local resources. Research is something they can (or should) be able to do.

- Setting up computers and/or installing software.

- Setting up data analysis tools (e.g. spreadsheets or simple databases).

- Tutoring (math, science, computers).

- Participate in programs for k-12 students focusing on engineering, math, science or computers.

- Simple repairs, maintenance or construction (hands on opportunities are great for the students and they learning how things work and how to design them better).

- Economic analyses for future opportunities.

This ended up to be an accurate assessment of their capabilities. It should be noted that since the students were receiving engineering credit for their work, they were evaluated on the engineering components, not the service. For example, if they were doing tutoring or classroom work, they

"Proceedings of the 2004 American Society for Engineering Education Annual Conference \& Exposition Copyright (C) 2004, American Society for Engineering Education" 
also had to do an analysis and report related to their service. We shared this with the community partners up front on the balance between service and academic learning. Service-learning seeks to strike a balance and we discussed this balance during our initial meetings with the prospective partners so that they understood our intentions. This was an important step as some of the initial responses were really seeking volunteers and had no real engineering component to them.

\section{Learning Objectives:}

We shared the learning objectives with the community partners as part of our initial discussions We also put these in front of the students at the beginning of their projects as the assignments were made. The learning objectives were :

- Appreciate the relationship of engineering and technology to the local community

- Understand one way they could use their engineering skills to benefit the local community

- Appreciate the interconnectivity of hands-on design and computer tool use

- Begin to employ effective teaming skills (students will perform their projects in teams of 3 or 4 )

- Ability to use computer tools (especially Excel) to solve engineering problems (this objective can be met with a "side-assignment" that is based on the service experience)

Timing: all of the projects needed to be done on the schedule for the ENGR 106 classes. Only one section that contained the learning community students participated in service-learning and with all of the sections following a common schedule, the schedule for the traditional projects was followed. This turned out to be fine with a few exceptions. A couple of the projects needed some follow-up after the final deadline but these were easily handled on an individual basis. At the beginning we explained the timing constraints to our community partners. Our projects started on the second week of classes and ended in the eighth week to meet this schedule.

The reporting and evaluation also mirrored the traditional project. Interim reports were due and evaluated in week 5 and final reports were due in week 8 . At each of these reporting times students produced a report with defined deliverables, completed peer evaluations and the community partners were asked to complete a six question evaluation for each team.

\section{Setting Expectations}

We tried to be clear and to communicate what the students should expect from the community partners and what the community partners should be expecting from the students. In order to do this most effectively, we identified the roles of the service providers (community partners) and discussed these with the community partners and the students before they began their work.

\section{We asked each Service Provider?}

- Willingness to work with three or four teams of students (each team will have 3 or 4 students on it) a clear description of the service opportunity.

- A contact name and phone number (email is also useful).

"Proceedings of the 2004 American Society for Engineering Education Annual Conference \& Exposition Copyright $\mathbb{0}$ 2004, American Society for Engineering Education" 
- A person to come to campus the week of Sept. $18^{\text {th }}$ to meet the students and introduce the community needs to the class.

- Supervision of the students on site. Our abilities are limited to directly supervise the students.

- Completing two short (one page) evaluations on the teams. An interim evaluation will simply ask if work has begun and the final evaluation will as to evaluate their work and the program as a whole.

We did NOT expect them to work around the students' schedules. If the students select a project with stated timelines, they are expected to abide by them. We do not accept late assignments in the ENGR 106 class and did not expect the service providers to go out of their way if students miss assigned times. We also did not expect them to provide transportation as the students have free access to the buses. We did ask that any service be performed within the range of the local bus system as the freshmen do not have cars.

\section{Implementation}

Implementation of the projects leveraged the infrastructure of the learning communities and the projects provided one of the more effective curricular ties between the courses. The projects were used as a substitute for the traditional first project in the ENGR 106 course (accounting for $15 \%$ of the course grade). We introduced the projects, collected reports and assigned grades for the projects in this course. We introduced the community partners during the Introduction To Engineering Seminars. Bringing the community partners to campus for their first meeting with the students was a significant benefit to the program. It allowed all of the students to hear first hand about the community partner and their expectations. Some of the community partners used this class time for orientations, such as Head Start.

Reflection on the projects and experiences was done through written reflections as part of their final reports in ENGR 106 and through the English and Communications classes. In the English classes, this took the form of essays and class discussions. In the Communications classes, this took the form of classroom discussions and a poster session where students presented their work and discussed with visitors the implications of the work.

\section{Projects Assigned}

The classes were divided by learning community division with each division of the introductory seminar having a different community partner. A complete listing of the projects is included as an appendix. The assignments were divided by service and engineering component

and were identified this way to the students. This division helped us and the community partners to talk about the value the experience was brining to their organization and to the learning of the students. It is important to distinguish that the students in service-learning were not getting academic credit solely for a service they provide, but for their demonstration of their work. They were evaluated on the deliverables they produced including their reports and analyses. Because engineering economy is one of the learning objectives for all of the projects (traditional and service-learning), an economic analysis was also required. Unless specified otherwise, this

"Proceedings of the 2004 American Society for Engineering Education Annual Conference \& Exposition Copyright (C) 2004, American Society for Engineering Education" 
component asked each team to determine the amount of a gift to establish an endowment to pay for the work they were providing and to continue this work into the future.

\section{Evaluations}

The first large-scale implementation of service learning was successfully implemented in the fall of 2003. Evaluations included course and instructor evaluations, which are shown in Figure 1. Both ratings were done on a five point scale. The section of the ENGR 106 Engineering Problem Solving Course had higher course and instructor ratings than any of the other sections. It is interesting to note that their performance was also higher on the common exams, lab assignments and the course overall. The service-learning section had a mean of $82 \%$ with the other sections having $78 \%$. This spread is unusual and is the subject of further evaluation.

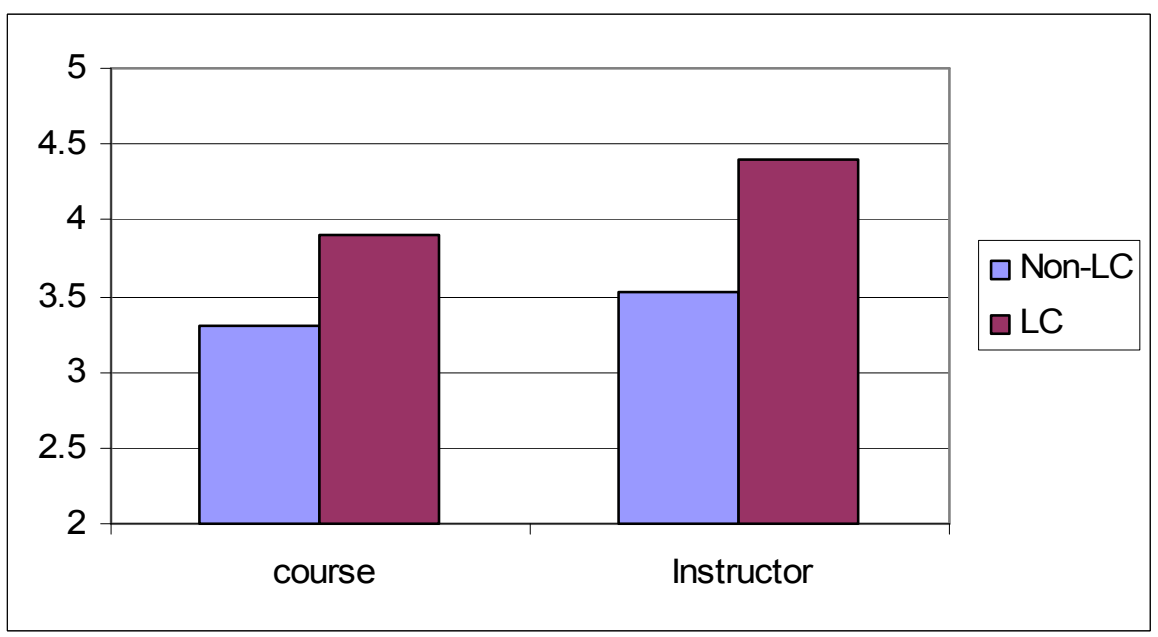

Figure 1: Course and Instructor Evaluations for ENGR 106, Engineering Problem Solving and Computer Tools, Fall 2003.

Students were also asked specifically about their experience in the learning community and with the service-learning projects. Students were asked to respond about their experience in the learning community division and their experience using a Likert scale with $5=$ Strongly Agree, $4=$ Agree, $3=$ Neutral, 2=Disagree, $1=$ Strongly Disagree. Figures 2 and 3 graphically show the number of students giving each response. The data show very high level of satisfaction with the learning community experience. A majority of students report that their experience has been enhanced and they would re-enroll in the learning community with a required servicelearning component. 


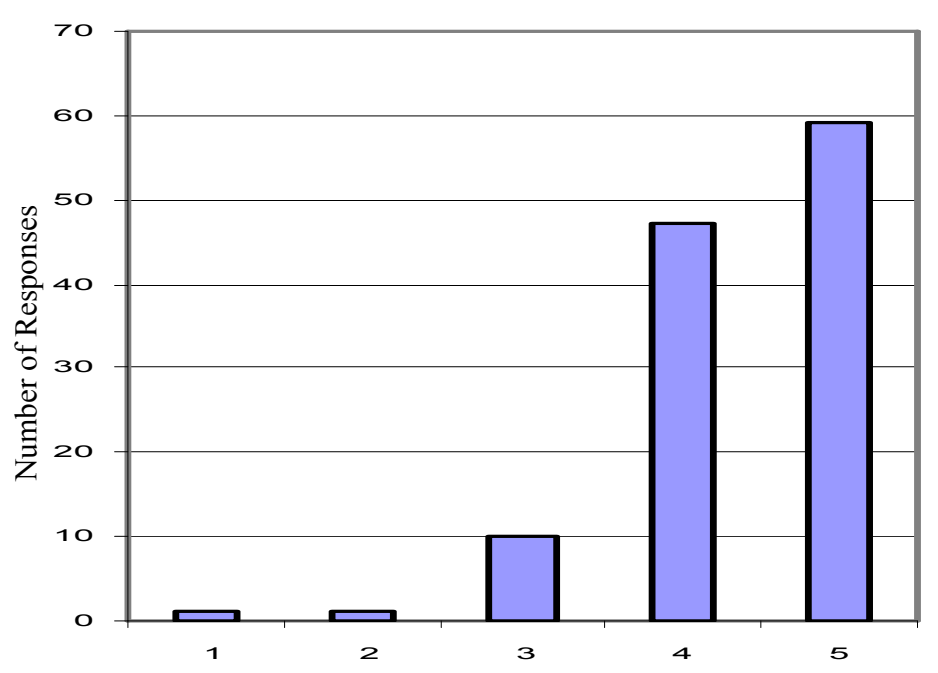

Figure 2: Student responses to the question "My participation in the learning community enhanced my first-year experience"

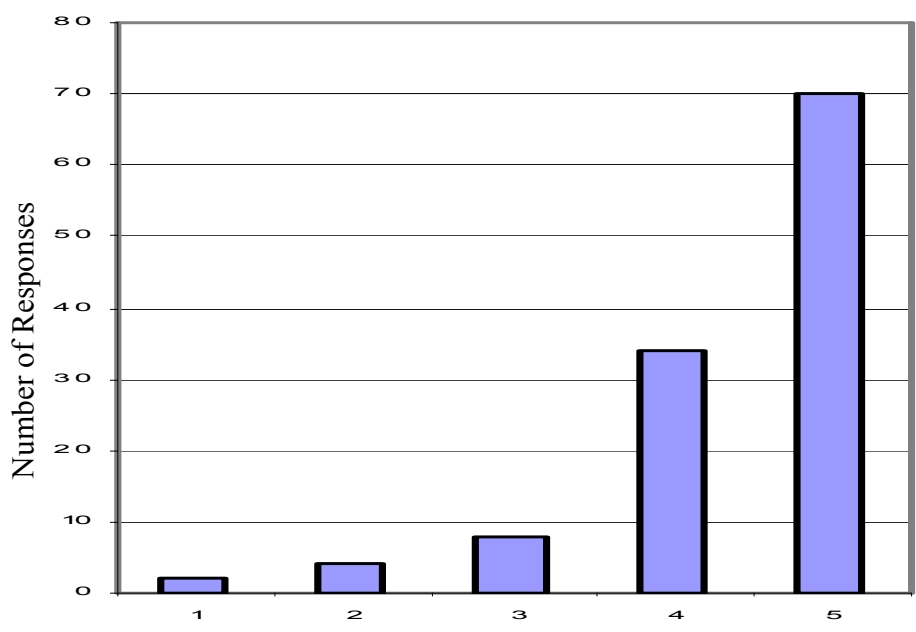

Figure 3: Student responses to the question "If I would starting my freshman year again in engineering, I would enroll in a learning community"

When asked specifically about the service-learning project, only 8 students report that they would not chose a service-learning project over a traditional project as shown in Figure 4. This is very satisfying considering issues that sprang up with new community partners during the projects. 


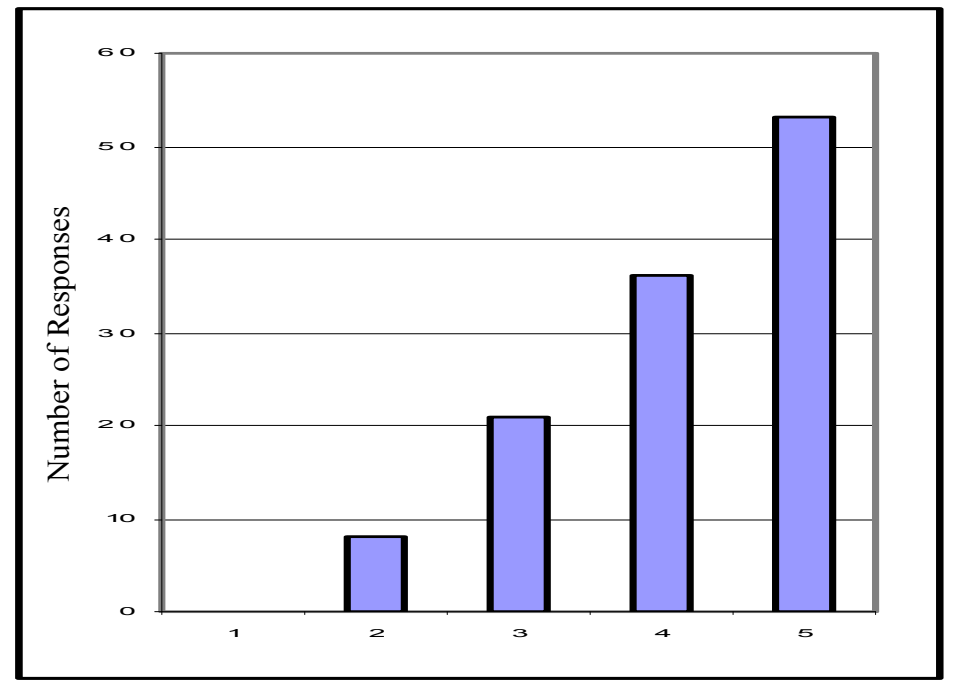

Figure 4: Student responses to the question "Given the choice of a traditional ENGR 106 project and the service-learning project, I would select a service-learning project"

The literature shows that expanding the view of engineering can positively impact the diversity of the engineering population. Figure 5 shows that many of the students reported that their view of engineering was broadened with this community-based project.

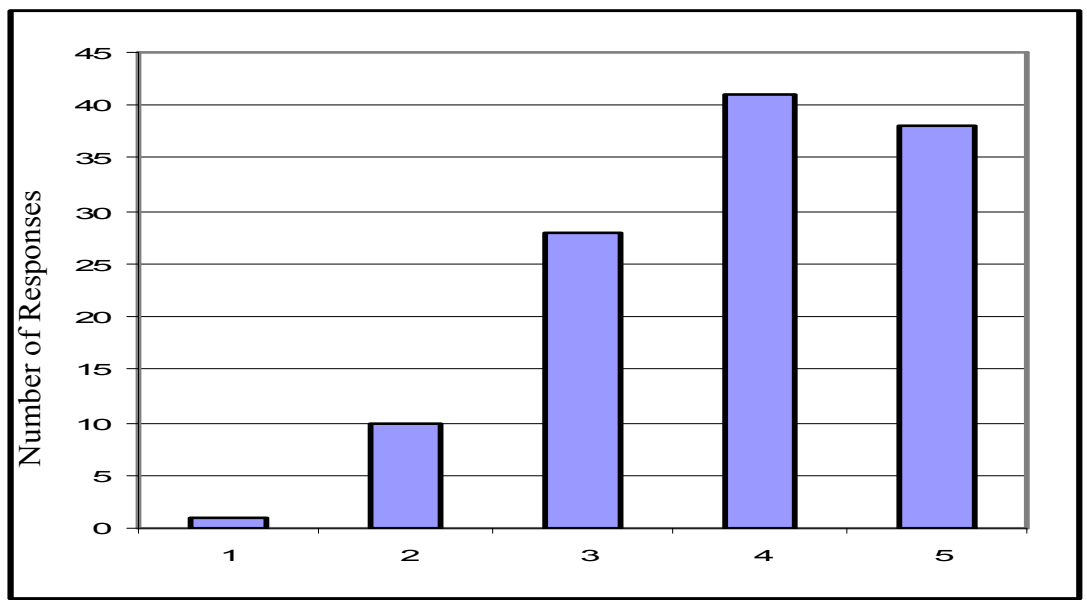

Figure 5: Student responses to the question "The service-learning project helped me see a broader view of engineering"

Students were also asked if they felt that they used "engineering skills" during the service-learning projects, Figure 6 . These results were mixed. It was interesting to find in

"Proceedings of the 2004 American Society for Engineering Education Annual Conference \& Exposition Copyright (C) 2004, American Society for Engineering Education" 
follow-up discussions on what constituted "engineering skills" for the students. Follow up discussions as part of the reflection activities found that many students felt design was engineering and other aspects of engineering such as analysis were not. For example, teams that preformed analyses on commercial software packages for implementation at their community partner did not feel they had done "real engineering". They felt that if they had actually written code and produced a piece of software, that would have constituted engineering. A feasibility study was not.

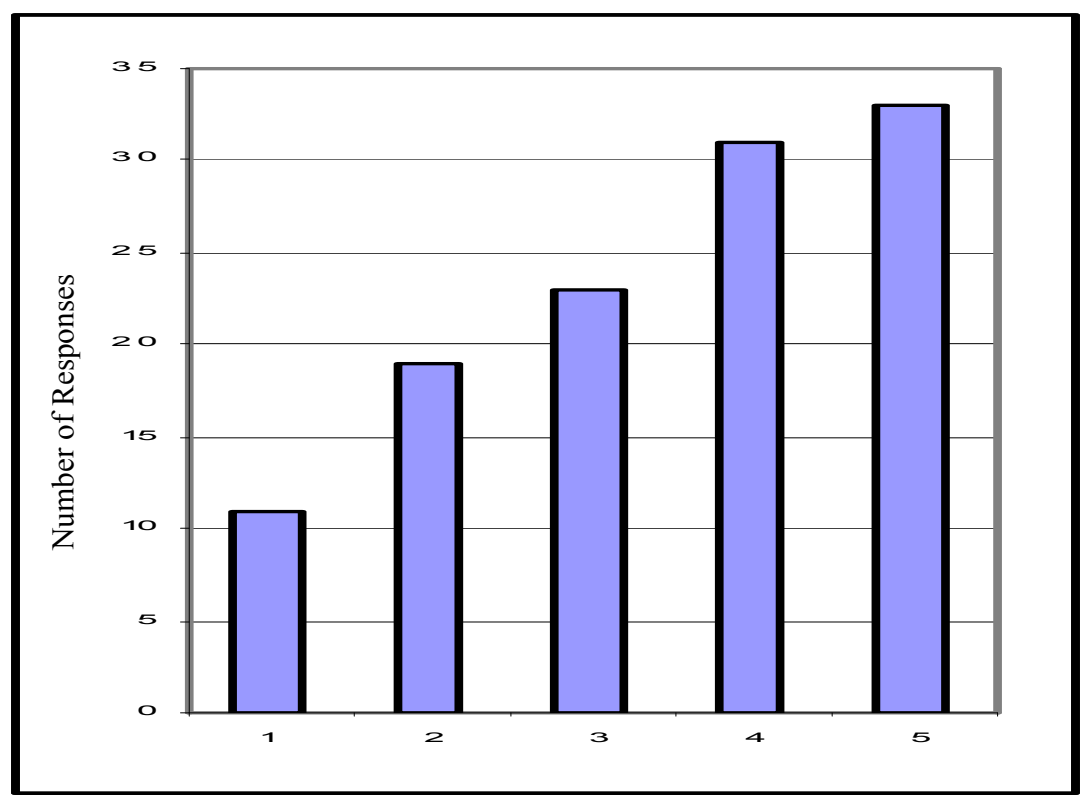

Figure 6: Student responses to the question "I used engineering skills in the service-learning project"

Evaluations from the community partners was positive. While there were issues that must be addressed for future semesters, all of the community partners indicated interested in continuing next year. Some of the concerns and changes they suggested included timing of the projects, many wanted longer projects. Some requested fewer teams so that they could work more closely with them. These changes are being considered as plans are being made for the next year's program.

\section{Conclusions}

Service-learning was successfully implemented on a large scale in a first-year engineering program as a curricular tie between three clustered courses as part of a learning community. Students report a high level of satisfaction with their overall experience. A significant majority would choose service-learning over a traditional project given the choice again. Students also report that their experience broadened their view of engineering. Further

"Proceedings of the 2004 American Society for Engineering Education Annual Conference \& Exposition Copyright $\mathbb{0}$ 2004, American Society for Engineering Education" 
studies are needed to understand the student experience and the impact that this experience has had on the student. A study is planned to conduct interviews with students involved in the program and are currently underway. The retention of students in engineering and in the university will be monitored as they progress through their college years.

Acknowledgement: This project was made possible with a generous grant from Hewlett Packard Philanthropy

\section{BIBLIOGRAPHIC INFORMATION}

ABET (2000). Criteria for Accrediting Engineering Programs. The Engineering Accreditation Commission of The Accreditation Board for Engineering and Technology.

http://www.abet.org/eac/eac.htm.

ABET (2002). Engineering Criteria 2002-2003, Accreditation Board for Engineering and Technology, http://www.abet.org/criteria.html, May 2002.

ASEE (1994). Engineering Education for a Changing World. Joint project report of the Engineering Deans Council and the Corporate Roundtable of the ASEE. http://www.asee.org.

ASEE (1995). Educating tomorrow's engineers. ASEE Prism, 11-15, May/June.

Astin, A. W. (1993). Engineering Outcomes. ASEE Prism, 27-30, September.

Bodner, G. M., D. MacIsaac, D., \& White, S. R. (1999). Action Research: Overcoming the Sports Mentality Approach to Assessment/Evaluation, University Chemistry Education, 1999, 3(1), 31-36.

Catalano, G. D., Wray, P., and Cornelio, S. (2000). Compassion Practicum: A Capstone Design Experience at the United States Military Academy, Journal of Engineering Education, Vol. 90, No. 4, Oct. 2000, pp. 471-477.

Coyle, E. J., Foretek, R., Gray, J. L., Jamieson, L. H., Oakes, W. C., Watia, J. \& Wukasch, R. (2000). EPICS: Experiencing engineering design through community service projects. 2000 ASEE Annual Conference, Charlotte, NC, June 2000.

Coyle, E. J., Jamieson, L. J. \& Dietz, H. G. (1996). Long-term community service projects in the Purdue engineering curriculum. 1996 ASEE Annual Conference, Washington, D.C., June 1996.

Coyle, E. J., Jamieson, L. H. \& Sommers, L. S. (1997). EPICS: A model for integrating service-learning into the engineering curriculum. Michigan Journal of Community Service Learning, 4, 81-89, Fall 1997.

Dahir, M. (1993). Educating Engineers for the Real World. Technology Review, pp. 14-16, Aug./Sept. 1993.

Duffy, J., Tsang, E., and Lord, S. (2000). Service-Learning in Engineering: What, Why, and How? Proceedings of the ASEE 2000 Annual Conference, St. Louis, Missouri, June 2000

"Proceedings of the 2004 American Society for Engineering Education Annual Conference \& Exposition Copyright (C) 2004, American Society for Engineering Education" 
Dutson, A. J., Todd, R. H., Magleby, S. P. \& Sorensen, C. D. (1997). A review of literature on teaching engineering design through project-oriented capstone courses. Journal of Engineering Education, 86(1), 17-28, January 1997.

Dym, C. L. (1994). Teaching design to freshmen: style and content. Journal of Engineering Education, 83(4), 303-310, October 1994.

Felder, R. M. \& Brent, R. (2001). Effective Strategies for Cooperative Learning. Journal of Cooperation and Collaboration in College Teaching, 10(2). 69-75.

Guedelhoefer, L., Jones, J. D., Davies, P., Coyle., E. J. \& Jamieson, L. H. (2000). Engineering education, beyond the books. 2000 ASEE Annual Conference, Charlotte, NC, June 2000.

Hissey, T. W. (2000) Education and Careers 2000. Proceedings of the IEEE, 88(8), 1367-1370, August.

Hobson, R. S. (2000). Service-Learning as an Educational Tool in an Introduction to Engineering Course, Proceedings of the ASEE 2000 Annual Conference, St. Louis, Missouri, June 2000.

Hughes, J. L. (2001). Incorporating Project Engineering And Professional Practice Into The Major Design Experience, Proceedings of the 2001 Frontiers in Education Conference.

Jamieson, L. H., Coyle, E. J., Harper, M. P., Delp, E. J. \& Davies, P. (1998). Integrating engineering design, signal processing, and community service in the EPICS program. 1998 IEEE International Conference on Acoustics, Speech, and Signal Processing, Seattle, WA, May 1998, 1897-1900.

Jamieson, L. H., Oakes, W. C. \& Coyle, E. J. (2001). Documenting service learning to meeting EC 2000. 2001 Frontiers in Education Conference, October 2001.

Jamieson, L. H., Oakes, W. C. \& Coyle, E. J. (2002). EPICS: Serving the community through engineering design projects. In Learning to Serve: Promoting Civil Society Through Service Learning, 277-295. Norwell, MA: Kluwer Academic Publishers, Norwell, MA.

Lueptow, R. M. (1994). Student participation, faculty involvement, and costs in the NGV challenge - a large-scale automotive design project. Journal of Engineering Education, 83(2), 182-184, April.

Matyas, M. L. \& Malcolm, S. (1991). Investing in Human Potential: Science and Engineering at the Crossroads. AAAS, Washington, D.C.

Nagchaudhuri, A., Eydgahi, A., and Shakur, A. (2000). SLOPE: An Effort Towards Infusing ServiceLearning into Physics and Engineering Education, Proceedings of the ASEE 2000 Annual Conference, St. Louis, Missouri, June 2000.

Noddings, N. (1992). Gender and Curriculum, from the Handbook of Research on Curriculum, edited by P. W. Jackson, New York: Macmillan.

Oakes, J., Gamoran, A., \& Page, R. N. (1992). Curriculum Differentiation: Opportunities, Outcomes, and Meanings, from the Handbook of Research on Curriculum, edited by P. W. Jackson, New York: Macmillan.

Oakes, W. C., Coyle, E. J. \& Jamieson, L. J. (2000). EPICS: A model of service learning in an engineering curriculum. 2000 ASEE Annual Conference, Charlotte, NC, June 2000.

"Proceedings of the 2004 American Society for Engineering Education Annual Conference \& Exposition Copyright (C) 2004, American Society for Engineering Education" 
Oakes, W. C., Krull, A., Coyle, E. J., Jamieson, L. J. \& Kong, M. (2000). EPICS: Interdisciplinary service learning using engineering design projects. 2000 Frontiers in Education Conference, October 2000.

Oakes, W. C., Jamieson, L. H. \& Coyle, E. J. (2001). Meeting EC 2000 through service learning. 2001 ASEE Annual Conference, June 2001.

Oakes, W. C. \& Rud, A. G. Jr. (2001). The EPICS model in engineering education: Perspective on problem solving abilities needed for success beyond school. In Beyond Constructivism: A Models \& Modeling Perspective, H. Doerr \& R. Lesh, eds., Lawrence Erlbaum Associates, Inc., Hillsdale, NJ.

O’Hear, A. (1996). Verstehen and humane understanding, Cambridge University Press, Cambridge.

Olson, G. M., Malone, T. W., \& Smith, J.R. (2001). Coordination Theory and Collaboration Technology, Lawrence Erlbaum Associates.

Patton, M. Q. (1990). Qualitative Evaluation and Research Methods $2^{\text {nd }}$ Edition, Sage: Newbury Park, CA.

Peterson, C. R. (1993). Why integrate design? ASEE Prism, 26-33, May 1993.

Quinn, R. G. (1993). Drexel's E4 program: A different professional experience for engineering students and faculty. Journal of Engineering Education, 82(4), 196-202, October 1993.

Rosser, S. V. (1990). Female-Friendly Science. Pergamon Press, Elmsford, NY.

Rosser, S. V. (1995). Teaching the Majority: Breaking the Gender Barrier in Science, Mathematics, and Engineering. Teachers College Press, New York, NY.

Seymour, E. \& Hewitt, N. (1997). Talking About Leaving: Why Undergraduates Leave the Sciences, Boulder, CO: Westview Press.

Spindler G. \& Spindler, L. (1992). Cultural process and ethnography: An anthropological perspective. In the Handbook of Qualitative Research in Education, edited by MD LeCompte, W. L. Millroy, and J. Preissle. New York: Academic Press.

Stott, N. W., Schultz, W. W., Brei, D., Winton Hoffman, D. M., and Markus, G. (2000). ProCEED: A Program for Civic Engagement in Engineering Design, Proceedings of the ASEE 2000 Annual Conference, St. Louis, Missouri, June 2000.

Tinto, V. (1993). Leaving College: Rethinking the Causes and Cures of Student Attrition, Chicago: University of Chicago Press.

Todd, R. H., Magleby, S. P., Sorensen, C. D., Swan, B. R. \& Anthony, D. K. (1995). A survey of capstone engineering courses in North America. Journal of Engineering Education, 84(2), 165-174, April 1995.

Tsang, E., editor (2000). Projects That Matter: Concepts and Models for Service-Learning in Engineering. Washington, D.C.: AAHE.

"Proceedings of the 2004 American Society for Engineering Education Annual Conference \& Exposition Copyright (C) 2004, American Society for Engineering Education" 
Valenti, M. (1996). Teaching tomorrow's engineers. Mechanical Engineering Magazine, 118(7), 64-69, July 1996.

\section{Biographical Information}

WILLIAM C. OAKES is an Assistant Professor in the Department of Freshman Engineering at Purdue University, where he is a Co-Director of the EPICS Program. He has served on the board of the ASEE Freshman Programs and Educational Research Methods Division and the Steering Committee FIE. He is a former recipient of the ERM Apprentice Faculty Grant and is an Indiana Campus Compact Fellow.

Michael Thompson is a Ph.D. student in Chemical Education in the School of Science at Purdue University. He received his B.S. from St Joseph's College and his M.S. in Biochemistry from Purdue University.

"Proceedings of the 2004 American Society for Engineering Education Annual Conference \& Exposition Copyright (C 2004, American Society for Engineering Education" 


\section{APPENDIX - Listing of Projects}

\section{Community and Family Resource Center/ Head Start}

\section{Team 1}

\section{Description of Service:}

To observe in a Head Start classroom and to provide ideas of technology that will enhance a preschool age child's experience in a specific area of the classroom.

\section{Desired Deliverables:}

A report on how to enhance the computer area of the classroom

- Technology/Software available to enhance the educational development of a 3-5 year old child

- Include specific technology and components, software and pricing

- How would this technology benefit the classroom

\section{Team 2}

\section{Description of Service:}

To observe in a Head Start classroom and to provide ideas of technology that will enhance a preschool age child's experience in a specific area of the classroom.

\section{Desired Deliverables:}

A report on how to enhance the science area of the classroom

- Science Tools/Technology available to enhance the educational development of a 3-5 year old child. A cad drawing of the educational tool to be developed.

- Include specific items that would need to be purchased along with detailed costs

- How would this technology benefit the classroom

\section{Team 3}

\section{Description of Service:}

"Proceedings of the 2004 American Society for Engineering Education Annual Conference \& Exposition Copyright (C) 2004, American Society for Engineering Education" 
To observe in a Head Start classroom and to provide ideas of technology that will enhance a preschool age child's experience in a specific area of the classroom.

\section{Desired Deliverables:}

A report on how to enhance the manipulative area (building/construction area) of the classroom

- Materials/Technology available to enhance the educational development of a 3-5 year old child

- Include specific items that could be purchased and detailed costs.

- How would this technology benefit the classroom

\section{Greater Lafayette Soccer Alliance}

\section{Team 1}

Description of service:

Conduct a survey of existing software tools and commercial products that could be used to further automate the data management of the Greater Lafayette Recreational Soccer Alliance (GLRSA). This research should include a survey of commercial products and surveys of similar youth organizations in other cities (perhaps near your home towns).

Desired deliverables at the end of the project:

A report which outlines the current state of the art of commercially available software tools to be used by volunteer-run youth athletic organizations. The report should provide a description of alternatives available and a recommendation of one or two packages or combinations of software for the GLRSA to look at for future implementation. The report should highlight which functions that are currently done by hand could be automated and which would remain manual operations.

\section{Team 2:}

Description of service:

Conduct a survey of existing software tools and commercial products that could be used to further automate the data management of the Greater Lafayette Recreational Soccer Alliance (GLRSA). This research should include a survey of commercial products and surveys of similar youth organizations in other cities (perhaps near your home towns).

Desired deliverables at the end of the project:

A report which outlines the current state of the art of commercially available software tools to be used by volunteer-run youth athletic organizations. The report should provide a description of

"Proceedings of the 2004 American Society for Engineering Education Annual Conference \& Exposition Copyright (C) 2004, American Society for Engineering Education" 
alternatives available and a recommendation of one or two packages or combinations of software for the GLRSA to look at for future implementation. The report should highlight which functions that are currently done by hand could be automated and which would remain manual operations.

\section{Team 3:}

Description of service:

Research ways to design a custom database system using on-campus resources including EPICS teams or design classes that work with database design (e.g. CPT, CGT and/or CS). Explore the feasibility of having a Purdue class design something custom including issues related to maintenance and future upgrades.

Desired deliverables at the end of the project:

A report with recommendation to use or not to use Purdue design classes to develop an upgraded data management system for the GLRSA. The report should include options that were examined and a detailed list of contacts that were made and the results of those contacts.

\section{Team 4:}

Description of service:

Conduct a feasibility study for an automated enrollment system for the GLRSA. Define what are the technical and ethical issues that such a system would have to address including payment options, verification of player identity and privacy issues. Research and explore the feasibility of a web-based enrollment system.

Desired deliverables at the end of the project:

A report on the feasibility of a web-based enrollment system for the GLRSA including recommendations to implement such a system or not and detailing the major technical hurdles that must be addressed.

\section{Caregiver Companion}

Description of Service: Caregiver Companion is a respite for caregivers, housekeeping, transportation, laundry, minor repairs for the ill frail and disabled who need a little help to remain living in their own home rather than move to an assisted living or nursing home.

"Proceedings of the 2004 American Society for Engineering Education Annual Conference \& Exposition Copyright (C) 2004, American Society for Engineering Education" 
Your teams will collaborate to produce a web site for Caregiver Companion. Three teams from your class will collaborate to produce one working website. The phases of the project will include

1. Develop specifications for the website, what must it do, where will it be housed, who should be able to modify it and how.

2. Brainstorm ideas and designs for the website.

3. Selection of design - teams will collaborate with the staff of Caregiver to select a design from the preliminary ideas

4. Development - the three teams will split up the development of the website into three parts to produce one working website

5. Deployment - one team should have primary responsibility for the deployment of the website onto the server that will host the site and should work with the staff to insure it is functional and that they are trained to maintain it.

Desired Deliverables at the End of the Project: A working website delivered on a CD and installed on a server that will host the site. Training materials on how to maintain and/or modify the site if needed will be provided to Caregiver Companion and at least one staff person will be trained on how to maintain the site after completion of the project.

Boiler Volunteer Network

\section{Team 1}

\section{Description of service:}

Conduct a survey of existing software tools and commercial products that could be used to further automate the data management of the Boiler Volunteer Network (BVN) This research should include a survey of commercial products and surveys of similar campus organizations on other campuses (perhaps near your home towns).

"Proceedings of the 2004 American Society for Engineering Education Annual Conference \& Exposition Copyright (C) 2004, American Society for Engineering Education" 


\section{Desired deliverables at the end of the project:}

A report which outlines the current state of the art of commercially available software tools to be used by volunteer-run youth athletic organizations. The report should provide a description of alternatives available and a recommendation of one or two packages or combinations of software for the BVN to look at for future implementation. The report should highlight which functions that are currently done by hand could be automated and which would remain manual operations.

\section{Team 2}

\section{Description of service:}

Conduct a survey of existing software tools and commercial products that could be used to further automate the data management of the Boiler Volunteer Network (BVN) This research should include a survey of commercial products and surveys of similar campus organizations on other campuses (perhaps near your home towns).

\section{Desired deliverables at the end of the project:}

A report which outlines the current state of the art of commercially available software tools to be used by volunteer-run youth athletic organizations. The report should provide a description of alternatives available and a recommendation of one or two packages or combinations of software for the BVN to look at for future implementation. The report should highlight which functions that are currently done by hand could be automated and which would remain manual operations.

\section{Team 3:}

\section{Description of service:}

Research ways to design a custom database system using on-campus resources including EPICS teams or design classes that work with database design (e.g. CPT, CGT and/or CS). Explore the feasibility of having a Purdue class design something custom including issues related to maintenance and future upgrades.

Desired deliverables at the end of the project: A report with recommendation to use or not to use Purdue design classes to develop an upgraded data management system for the Boiler Volunteer Network. The report should include options that were examined and a detailed list of contacts that were made and the results of those contacts.

"Proceedings of the 2004 American Society for Engineering Education Annual Conference \& Exposition Copyright (C) 2004, American Society for Engineering Education" 


\section{Team 4}

Description of Service: While the other teams explore long-term software improvements for the Boiler Volunteer Network, implement using Excel, Access or other software a simple system to reduce the manual information management done by the BNV.

Desired Deliverables at the End of the Project: A working software system that will enhance the work of the Boiler Volunteer Network. Documentation on the system must be delivered and the staff trained in how to use the new system.

Trinity Mission

\section{Team 1:}

Description of service: One team would be assigned to Trinity Mission Outlet Store. Trinity Mission Outlet store frequently receives donated computers and various computer components. Trinity Mission proposes that the team of students would correctly match together all the computers and subsequent components. The team would tag the computer and components in such a way that if the computer and components were separated and/or misplaced the tags would instruct a person as to which computer the components belonged to. The team would then determine if the computer would work and the capacity of each computer. If the computer did not work the team would repair the computer. The team would then color code the components to specific computers and detail the operating system, available memory, etc. and programs that were currently installed on the hard drive for each computer. These details would all be found in a booklet $(3$ copies $=1$ attached in some fashion to the computer, 1 given to the Store manager, and 1 given to the Executive Director of Trinity Mission).

The team will then develop a manual or a wall poster of procedures that would instruct staff and residents and volunteers on learning to recognize compatible computer and computer components as they were received through the donations. The manual and/or wall poster should contain some type of decision tree helping staff, residents, and volunteers to correctly assemble a computer with compatible components. (Example: if you have a printer cable with pins verses a USB printer cable). This manual should also list out common problems with potential solutions for the problem as in a trouble- shooting guide. The final part of the project is for the team to hold a training class at the store and teach staff, residents, and volunteers all of the above. (The Outlet store manager would be the supervisor of the students for this project.

\section{Team 2:}

\section{Description of service:}

"Proceedings of the 2004 American Society for Engineering Education Annual Conference \& Exposition Copyright (C) 2004, American Society for Engineering Education" 
Another team will be assigned to Trinity Mission Outlet store. Their project will be to examine small appliances/machines to determine if they are in working order. If they are not in working order the team should repair the appliance (if possible). Upon repair of the appliance the team should create a manual, (1 copy for store manager, 1 copy to Executive Director), that includes step-by-step instructions (complete with photographs/diagrams/parts labeled/tools needed) for the repair of each type/brand of appliance/machine. Included in this manual should be a troubleshooting guide. Upon completion of project the team will present a training session to the staff, residents and volunteers on repairing and trouble-shooting appliances. (The Outlet Store's assistant manager will be the supervisor of the team for this project).

\section{Team 3:}

Description of service: The team will be assigned to the Trinity Mission Administrative office. The project will be based on the floor plans of our Crawfordsville facility and existing computers. The project will be to examine existing computers and determine if the computers work and the capacity of each computer. If the computer did not work the team would repair them. The team would detail the operating system, available memory, etc. and programs that were currently installed on the hard drive for each computer. These details would all be found in a manual ( 1 copy to the Executive Director and 1 copy to remain with the computers). The team would then design and layout the computer placement and networking of the facility according to the floor plans. (This includes a server, printers, DSL lines, etc.). The final product of this project would be the completion of a manual and a detailed plan for networking and placement of the computer system for Trinity Mission's Crawfordsville facility. The team would train the Executive Director and/or his designees on the manual and the detailed plan. (The Executive Director and/or his designees would be the supervisor of the students for this project.

\section{Hanna Center}

\section{Teams:}

\section{Description of service:}

Tutoring of children ages 5-12 in math, science and computer subjects as part of an after school program at the Hanna Center. Each team will need coordinate schedules to have appropriate numbers of students there each day of the week.

\section{Desired deliverables at the end of the project:}

1. Enhanced learning by the $5-12$ year old participants in the tutoring program

"Proceedings of the 2004 American Society for Engineering Education Annual Conference \& Exposition Copyright (C) 2004, American Society for Engineering Education" 
2. Report on the tutoring experience and process

a. Individual experiences and reactions

b. Team report on ways to enhance the learning experience using current technology tools (note that teams 4 and 5 will focus on this)

\section{Teams:}

\section{Description of service:}

Perform an analysis of the learning environment for tutoring of the 5-12 year old students that teams 1-3 are working with. Research technology and materials that are available to enhance the learning of the children that are part of the tutoring programs. It is strongly recommended that you accompany members of teams 1-3 to their tutoring sessions and/or spend time observing the children to be able to frame your recommendations.

\section{Desired deliverables at the end of the project:}

A report will be delivered to the Hanna Center that details options that they could employ to enhance the learning environment for the tutoring programs. Include opportunities to use current technology to help the children - note that these technologies do not have to be used exclusively at the Hanna Center.

\section{Freshman Engineering Outreach}

Description of Service: Three teams will develop parallel projects and are expected to develop independent projects but must coordinate so that the projects can be done during the same program. Each team will develop a hands-on educational program to introduce elementary students to a basic engineering process/concept within one (or more) engineering disciplines.

\section{Desired Deliverables at the End of the Project:}

45 minutes lesson presented at local elementary school. Program should be ageappropriate and, ideally, contain teaching, demonstration and a student project. Program should be easy to replicate and adapt to other age groups. Projects will be implemented with students from a local school and will be documented so that they can be replicated by other students working with pre-college students.

"Proceedings of the 2004 American Society for Engineering Education Annual Conference \& Exposition Copyright (C) 2004, American Society for Engineering Education" 
Name of Organization: Imagination Station

Description of Service: Four teams will collaborate to enhance the environment of the Imagination Station (IS) in Lafayette by painting the HVAC ducting bright colors and by providing signage that teaches children who visit the IS about the engineering and science behind operation of the Imagination Station. Specific services that will be provided will be

- Prepping and painting of the HVAC ducting (while not traditional engineering, it will require coordination of all four teams, a great deal of planning and care for the execution to give it a professional look)

- Creation and deployment of small signs that are placed around the IS to illustrate the engineering and science behind the basic utilities. Teams will develop separate signs different subsystems as assigned below

○ Team 1 - Heating system, including the furnace and the fuel that powers the furnace

- Team 2 - Air conditioning including possible information on humidity of the building

○ Team 3 - Electrical systems, while you are not painting the conduit, you should provide signs to illustrate what is happening with the electrical systems and the technology behind it.

○ Team 4 - water systems, while you may not be painting these pipes, you should develop signs that teach something about the water systems and the technology behind it.

- A feasibility study of instrumentation that could be added later that would teach children about the principles illustrated in your signs. Specific instrumentation and costs should be included. If these instruments could be linked to computers for data collection, this should also be included.

\section{Desired Deliverables at the End of the Project:}

1. Professional looking and visually appealing HVAC ductwork

2. Visual Exhibits of how the utilities and support systems work in the IS

3. Reports with recommendations for instrumentation and potential uses

"Proceedings of the 2004 American Society for Engineering Education Annual Conference \& Exposition Copyright (C) 2004, American Society for Engineering Education" 
Name of Organization: Imagination Station

Description of Service: All four teams will be given the same task but are expected to develop independent and unique solutions to provide the Imagination Station (IS) with curriculum packets to be used in the fall 2004's after school program. Each curriculum packet should illustrate a different aspect of engineering and should be approved in advance by the IS contact. Each team must develop two complete curriculum packets which have been approved by the IS contact or delegated staff member.

In order to understand the level of the material that is needed and the design of the activities, each team member should plan to spend time at the IS when the after school program is going on or when other programs with children of similar ages are at the IS.

\section{Desired Deliverables at the End of the Project:}

1. At least two age appropriate curriculum packets for the IS after school programs illustrating engineering principles. Curriculum packets must include

a. Materials that are needed including specific items, where to purchase and associated costs

b. Learning objectives for the activity

c. Clear instructions of how to conduct the activity

2. Results of research and other ideas and/or leads that you found during your work

3. Calculation of the endowment needed to sustain this activity

Name of Organization: $\quad$ Science Bound

Description of Service: $\quad$ All teams will work with the director of Science Bound to develop feasibility studies on the development of engineering projects that students from the Indianapolis Public School (IPS) who are participating in the Science Bound program could perform to learn more about engineering. These projects would be performed during the Science Bound activity

"Proceedings of the 2004 American Society for Engineering Education Annual Conference \& Exposition Copyright (C) 2004, American Society for Engineering Education" 
time and at their local schools in Indianapolis. These projects would involve our freshman engineers through either direct contact in the schools in Indianapolis, through web-cams or email mentoring.

Students will provide reports and descriptions of projects and ideally conduct one project this fall.

Developing mentor relationships with IPS students via e-mail would also be welcomed.

Brainstorming other possibilities for interactions of future freshman engineering teams and IPS students participating in science bound.

All teams will have the same objective but are expected to develop independent ideas, projects and reports.

Desired Deliverables at the End of the Project: Reports containing descriptions and outlines of projects and/or mentoring opportunities for future freshman engineering teams that can be done with the students participating in Science Bound.

Active mentoring and/or contact with students in the science bound program are encouraged and should be summarized in any reporting.

\section{Habitat for Humanity}

Description of service: Habitat for Humanity International has an initiative that is called the $21^{\text {st }}$ Century Challenge where communities come together to eliminate substandard housing in an entire county (information is at http:/www.habitat.org/build/21st/default.html). Under this initiative, many organizations and the communities within a county must come together to pool and coordinate resources to accomplish the goal so a solution is larger that what Habitat for Humanity could do.

"Proceedings of the 2004 American Society for Engineering Education Annual Conference \& Exposition Copyright (C) 2004, American Society for Engineering Education" 
In 2001, the two sections of the engineering learning community did a preliminary survey of Lafayette to look at the needs of substandard housing. In this survey, they developed a preliminary rating system for housing. The results were presented to Habitat for Humanity and were then taken by the EPICS team that works with Habitat and the rating system was improved and made more detailed. A small area (about one block) was resurveyed using the new rating system.

What needs to be done next is for the new rating system to be used to resurvey the Lafayette area and establish a comprehensive survey of the city. The data from the first surveys can be used as a guide for the housing areas (note that there are more affluent areas in town that do not need to be resurveyed). The four teams from you class will need to collaborate on this project to share data and insure that you don't survey the same areas. Your teams should coordinate and divide the Lafayette area into four regions that need to be surveyed. Prioritize the areas using the previous data.

A second phase of the project is needed this semester and that is a plan for surveying the rest of the county. Again, the four teams must collaborate by dividing the county into quarters. Each team should examine their region and research where potential areas of concern would be, how large they are and what resources are needed to survey those areas. Use your experience surveying the Lafayette area to perform this analysis. You may need to find people who are familiar with the county and different regions to perform the analysis.

Desired deliverables at the end of the project: The teams should agree on basic formats of the reports so that the four reports can be combined into one summary for later analysis

1. Each team will provide a report on their regions of Lafayette

2. Each team will provide a report on their region of Tippecanoe county

3. For your regions, what is the estimated cost of eliminating substandard housing in the county? Use Excel to calculate the present value of this cost if the initiative will take ten years to complete.

"Proceedings of the 2004 American Society for Engineering Education Annual Conference \& Exposition Copyright (C) 2004, American Society for Engineering Education" 